ORIGINAL ARTICLE / ARTIGO ORIGINAL

\title{
Assessment of control and epidemiologic details of the schistosomiasis mansoni in Bananal, São Paulo, Brazil
}

\author{
Avaliação do controle e detalhes epidemiológicos \\ da esquistossomose mansoni em Bananal, São Paulo, Brasil
}

Horacio Manuel Santana Teles', Cláudio Santos Ferreira", Maria Esther de Carvalho'

\begin{abstract}
The purpose of our study in the municipality of Bananal, state of São Paulo, Brazil, was to stop the transmission of schistosomiasis mansoni. Particular emphasis was given to such items as the active surveillance and eventual treatment of hosts, mapping parasite foci, and increasing the extent of basic sanitation in the municipality. Now, our records indicate that the eradication of schistosomiasis in the municipality of Bananal is attainable. However, as the vector Biomphalaria tenagophila can still be found in some water bodies within this municipality, it remains included in the area where schistosomiasis is endemic, which calls for very strict measures to avoid the human cases of schistososomiasis. The expansion of the coverage of the basic sanitation network and treatment of Schistosoma mansoni cases diagnosed during periodic surveys are part of the plans to eradicate schistosomiasis in Bananal.
\end{abstract}

Keywords: Schistosomiasis mansoni. Diagnosis. Treatment. Control. Surveillance. Epidemiology.

IScientific researcher of Superintendência de Controle de Endemias - São Paulo (SP), Brasil.

"Professor at the Medical Biosciences Institute of Universidade de São Paulo - São Paulo (SP), Brasil.

Corresponding author: Horacio Manuel Santana Teles. Superintendência de Controle de Endemias. Rua Paula Souza, 166, CEP: 01027-000, São Paulo, SP, Brazil. Email: horacio@sucen.sp.gov.br

Conflict of interests: nothing to declare - Financing source: Superintendência de Controle de Endemias.

531

REV BRAS EPIDEMIOL APR-JUN 2014; 531-542 
RESUMO: O propósito do nosso trabalho no município de Bananal, estado de São Paulo, Brasil, foi o de interromper a transmissão da esquistossomose mansônica. Foi dada particular atenção a itens como: busca ativa e tratamento dos infectados, mapeamento dos focos de parasitas e aumento da abrangência do saneamento básico do município. Atualmente, nossos dados indicam que a provável erradicação da esquistossomose em Bananal é possível. Entretanto, como o vetor Biomphalaria tenagophila ainda pode ser encontrado em algumas coleções de água deste município, esta permanece incluída em área onde a esquistossomose é endêmica. Isto implica a adoção de medidas muito restritas para evitar novas ocorrências de casos humanos da doença. Fazem parte do plano de erradicação da esquistossomose a expansão da cobertura da rede de saneamento básico e o tratamento dos casos diagnosticados durante as investigações periódicas.

Palavras-chave: Esquistossomose mansônica. Diagnóstico. Tratamento. Controle. Vigilância. Epidemiologia.

\section{INTRODUCTION}

The disease caused by the trematode worm Schistosoma mansoni, is prevalent in tropical and subtropical regions of the globe. Its persistence in a community is dependent on biological and social determinants. In contact with water, $S$. mansoni viable eggs (contained in host's feces) hatch, liberating the free-swimming larvae (miracidia) infective to Biomphalaria genus snails. A process of multiplicative development produces large numbers of cercariae, infective to man, which are released from the snails into the water. The cercariae penetrate the human skin and, as metacercariae, gain access, through a rather complex route, to the veins of the portal system. The state of health of humans infected with $S$. mansoni will largely depend on their parasite burden, which is in turn closely related to the frequency and duration of exposures to water contaminated by cercariae.

Basic sanitation is fundamentally important for the control of sources of infection. As viable $S$. mansoni eggs are usually found in the feces of carriers during long periods of time, such cases must be treated without delay. According to the prevailing environmental conditions, the use of molluscicides can constitute a valid attempt at producing a temporary interruption of $S$. mansoni transmission ${ }^{1}$.

Recent estimates indicate that we must have at least 6 million infected people in Brazil $^{2}$. The widespread snail species Biomphalaria glabrata, Biomphalaria tenagophila, and Biomphalaria straminea are the vectors of $S$. mansoni in the Brazilian territory ${ }^{3}$.

During the middle 1970s, the "Special Program for the Control of Schistosomiasis" (Programa Especial de Controle da Esquistossomose) became responsible for the planning and implementation of prophylactic actions against schistosomiasis in the Northeastern states of Brazil $^{4}$. The availability of oxamniquine, an effective, single-dose new anti-schistosoma drug 
with a few restrictions and side effects ${ }^{1}$, was essential for the practicability of the Program. On the basis of a reduction of morbidity, new programs could be devised to control the transmission of schistosomiasis.

An important aspect of our action against endemic schistosomiasis was represented by the use of the simple and effective Kato-Katz microscopic technique to identify helminthes eggs and count them per gram (EPG) of feces ${ }^{5}$. Rough estimates of worm burdens based on EPG values were included in the patient's follow-up observations.

The first systematic attempt at controlling the transmission of mansoni schistosomiasis in the state of São Paulo dates back to the middle $1960 \mathrm{~s}^{6}$. Originally, the action against the parasite consisted almost exclusively in the use of molluscicides, chiefly niclosamide. At first, the "Campaign for Combating Schistosomiasis" (Campanha de Combate à Esquistossomose) followed the usual modus operandi. The anti-schistosoma treatment was too complex at that time and, due to the restrictions and side-effects of the drugs then available ${ }^{7}$, it had to be done in an out-patient section of a hospital.

The transmission of mansoni schistosomiasis in the state of São Paulo is associated with B. straminea, B. glabrata and, chiefly, B. tenagophila. The last is responsible for most of the $S$. mansoni foci and cases detected in this state ${ }^{8}$. This also applies to the municipality of Bananal, where the first foci and autochthonous cases were observed in the early $1970 \mathrm{~s}^{9}$. Since then, strict control measures reduced the probability of the occurrence of serious cases of the disease. Although the transmission of $S$. mansoni still persisted, complications had become less frequent. In Bananal, as well as in other municipalities of the state of São Paulo, besides the increased attention on the part of the health authorities, the success of the prophylactic plans was due to a gradual improvement in environmental salubriousness associated with some social and economical progress among the local inhabitants. The improvements in standard of living pointed toward lower prevalence and lower worm burdens and, therefore, a predominance of asymptomatic cases ${ }^{10}$.

In mid-1997, the Government of the state of São Paulo decided on a new policy: to design a specific plan to intensify the control of schistosomiasis. This plan aimed at a reduction of the prevalence of schistosomiasis to less than $1 \%$ by the year 2000. It was based on the active surveillance and treatment of all cases, by means of yearly examinations, of fecal samples and treatment of all cases diagnosed as infected. The sewage network would be expanded to include the whole urban residential area. This plan also promoted the integration of various sections of the state, the municipality, and other organizations involved in the control and prophylaxis of schistosomiasis mansoni.

The municipality of Bananal is situated in the region of the hydrographic basin of Paraíba do Sul river, which is popularly known as the "Valley of Paraíba river", in far Northeastern São Paulo ( $\left.22^{\circ} 40^{\prime} 44^{\prime \prime} \mathrm{S}, 44^{\circ} 19^{\prime} 08^{\prime \prime} \mathrm{W}\right)$. It is about $360 \mathrm{~km}$ from the Capital of the state and occupies an area of $620 \mathrm{~km}^{2}$ at an altitude of $560 \mathrm{~m}$ above sea level. It is bordered by the municipalities of Arapeí and São José do Barreiro (in the state of São Paulo), and Rezende, Barra Mansa, Rio Claro, and Angra dos Reis (in the state of Rio de Janeiro). Its population is 10,223 inhabitants, $74 \%$ of which are residents in the urban area ${ }^{11}$. Their livelihood is largely dependent on 
needlework, the manufacture of pieces of artisanship, and homemade fruit jellies and jams. The municipality of Bananal is rich in landmarks reminiscent of its past prosperity; it has much to offer in terms of impressive landscapes which constitute a major tourist attraction ${ }^{12}$.

The city area of Bananal is bisected by the Ribeirão Bananal (Bananal stream). Besides Centro, it has the districts Vila Bom Jardim and Palha, on the right bank of the river, and the districts of Niteroi, Laranjeiras, Cerâmica, and Três Barras on its left bank. The rural area of the municipality of Bananal comprises Rancho Grande, located near the SP-068 highway (Rodovia dos Tropeiros) and a cluster of houses in the km 10 of SP-247 highway, or highway of Sertão da Bocaina, a tract of the mountain range Serra do Mar, in the region.

\section{METHODOLOGY}

On an annual basis, containers to be returned with stool samples for examination were distributed among the local inhabitants. Fecal samples have been processed and examined according to the Kato-Katz ${ }^{5}$ technique from a period prior to the enhancement plan, until the year 2003. From 2004 onwards, vigilance was maintained by the use of gravity sedimentation applied to sieved fecal suspensions in water ${ }^{13}$, according to the technique of Hoffman et al. ${ }^{14}$. Oxamniquine had been prescribed, as an anti-schistosoma drug, until the year 2003 , when it was replaced by praziquantel. The standard dosages, according to body weight, recommended for our country were used.

Database retrieval and appropriation of information from case histories required access to information pertaining to previous epidemiological investigation on schistosomiasis from a document named "FE-5". This led to the creation of a new database with the home addresses of cases at the time of diagnosis and treatment.

The reason why this survey was started in 1994 was that the São Paulo Control Program did not, until that year, accept home addresses of human carriers of schistosomiasis as reference units for planning and executing control actions. The same Control Program established that the search for parasite eggs should be based on the examination of two slides from each fecal sample ${ }^{1,15}$. From 2004 onwards, the search for and surveillance of schistosomiasis cases were part of the routine work of the Family Health Program ("Programa de Saúde da Família").

The diagnosis and treatment of human cases consist of regular activities and the government health program provides with preservation of confidentiality of information. The techniques and other procedures described in this study are routines that do not require any submission to the ethics committee.

The cases were mapped according to cartographic rules. The geographic coordinates always referred to the front door of the homes registered at the time of diagnosis and treatment. We used a global positioning system and unit transverse mercator grid system, in DATUM WGS 84. The information obtained was processed with the aid of the program Idrisi Kilimanjaro, in a digital base which had its origin in the official plan of the urban area of Bananal, on a scale of 1:5,000. 
The activities of the foci were monitored by means of a monthly collection of snails from water bodies within the urban area. The snails were exposed to artificial light and crushed before examination under a low-power microscope ${ }^{16}$. The cercariae released from the infected snails were readily identifiable. To determine the boundaries of the foci and obtain their geographical coordinates, we selected the points of discharge of collective sewage observed until the year 2000 .

\section{RESULTS}

The total number of examinations of feces made during our investigation and the percentages of results positive for $S$. mansoni are shown in Table 1 . There has been a steady decline of these percentages since the year 2004 and, with the exception of the years 2008 and 2009, no new cases were found in the municipality of Bananal by the routine diagnostic service. Cases reported after the close of the Control Intensification Plan, in 2003, were not taken into consideration.

The treatment of positive cases was the responsibility of the local health unit. Further epidemiological investigation led us to conclude that all such cases were autochthonous of the municipality of Bananal. Until the year 2003, oxamniquine was used in the treatment of schistosomiasis. From that time onwards, praziquantel was used instead ${ }^{15}$. The fact that no imported cases were detected indicates that migration should not be considered as an important cause of the maintenance of $S$. mansoni foci in the municipality of Bananal. The cases diagnosed in Bananal were confirmed as autochthonous because of their origin and contacts restricted to local freshwater.

Table 1. Distribution, frequency, and percentage of the schistosomiasis mansoni diagnosed in localities of Bananal, São Paulo, Brazil (1994 - 2012).

\begin{tabular}{l|c|c}
\hline Locality & Frequency & Percentage \\
\hline Centro & 91 & 14.9 \\
\hline Vila Bom Jardim & 49 & 8.0 \\
\hline Palha & 206 & 33.7 \\
\hline Niterói & 39 & 6.4 \\
\hline Laranjeiras & 43 & 7.0 \\
\hline Cerâmica & 131 & 21.4 \\
\hline Fazenda Três Barras & 37 & 6.1 \\
\hline Rural area & 15 & 2.5 \\
\hline Total & 611 & 100.0
\end{tabular}


Concerning the evaluation of the intensity of infections, or parasitic burdens, expressed in terms of EPG, 70\% of the cases under study had counts below $96 \mathrm{EPG}$, indicative of light infections and infrequent liver damage. Nearly $30 \%$ of our cases had counts higher than or equal to $96 \mathrm{EPG}$, indicative of moderate infections and frequent hepatosplenic forms. Counts greater than 800 EPG were found in two cases. These values are usually associated with serious organic complications ${ }^{1,10,16}$. However, the clinical examination files kept in our epidemiological databases did not indicate any abnormality recognizable as pertaining to moderate or severe forms of schistosomiasis.

The search for new cases of schistosomiasis by means of active surveillance implemented as parasitoscopic examinations showed the greatest positivity rates during the interval between the years 1994 and 1997. From 1997 until 2003, when the intensification of schistosomiasis control reached its term, the fall in incidence and prevalence of schistosomiasis became evident. It is admitted that the chances of the occurrence of severe disease were reduced.

The frequency distribution of cases, by locality, in urban and rural areas is shown in Table 1. To map out this distribution, we had to omit 80 or $11.6 \%$ cases from the table because important data about houses were unreadable in the notification forms. It is worth noticing that although the Palha and Cerâmica districts together include only $20 \%$ of the urban population, they had more than $55 \%$ of all cases of schistosomiasis diagnosed during our investigation.

Our address survey indicated that all cases were distributed among 240 domiciles in eight districts of the city. Despite the fact that as much as $2.5 \%$ of the cases are registered as belonging to rural areas, their case histories consistently pointed to contact with water bodies located in urban areas. Individual records indicated re-infections in up to four different opportunities. Multiple re-infections within one domicile, occurring within one or more years, have also been registered.

Figure 1 shows the proportions of positives among the fecal samples examined before the implementation of the plan for the intensification of control, from 1994 to 2000; and after 2004, within the period of surveillance and monitoring of the preventive measures, then incorporated to the routine activity in the Family Health Program.

Figure 2 shows the spatial distribution of water bodies and routes of access to them, the city district street plans, and the regions identified as foci of schistosomiasis, as well as those connected with cases diagnosed during the epidemiological investigation. The sites where snails infected with $S$. mansoni were captured and those where untreated human sewage from single houses or the municipality sewerage was regularly dumped did not coincide. Furthermore, Figure 2 brings out the epidemiological situation which results from the concentration of households around a region of the urban course of Bananal stream where cercaria-shedding snails have been captured. This region includes the Niteroi, Palha, Três Barras, and Cerâmica districts.

From 1998 to 2000, cercaria-shedding snails had been collected from the Ribeirão Bananal (Bananal stream), the mouth of a stream called Antônio Siqueira, and a site near the mouth of stream Lava-Pés, all of them located in the city center ${ }^{17}$. After that period, even at the end of the year (from October to December), when infected snails used to be most frequently 


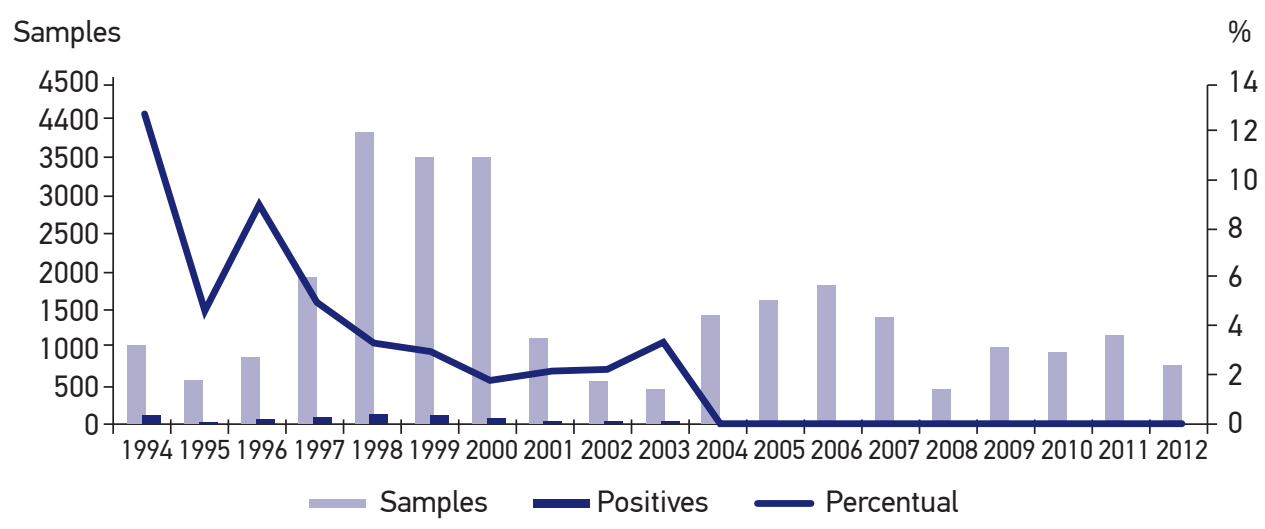

Figure 1. Fecal samples, cases, percentage, and positivity of schistosomiasis mansoni in Bananal, São Paulo, Brazil (1994 - 2012).

found, none of them had been captured. Besides B. tenagophila, water bodies in Bananal are colonized by Drepanotrema cimex, Physa marmorata, and Lymnaea columella, which are not associated with the transmission of $S$. mansoni.

Figure 3 shows data pertaining to basic sanitation in Bananal, during the years 1994-2010. At first, only $50 \%$ of the households were connected to the city sewerage; but in the year 2000 this had been changed to $90 \%$. All sewage is adequately treated.

\section{DISCUSSION}

The first cases of schistosomiasis in Bananal were recorded during the $1970 \mathrm{~s}^{9}$. No information is available about past imported cases of this infection or to suggest that the mass population displacement of the past decade, mentioned by Machado ${ }^{4}$ as determinant of the disease dissemination throughout the Brazilian territory, involved the municipality of Bananal.

It seems that the main reason for the introduction of $S$. mansoni $i^{18}$ in the municipality of Bananal and into the valley of the Paraiba River itself was the concentration of Africans put to work as slaves, in those regions, on extensive coffee plantations during the interval from the late $19^{\text {th }}$ century. The unsanitary conditions observed during the time of slavery stimulated the worm adaptive changes required by a new environment. As such situation did not change, the transmission of the parasite persisted. Although there is a concrete possibility of the introduction of $S$. mansoni in a remote epoch, the account of the first cases of the disease which it causes is dated from the middle 1970s and the efforts to find infected snails ocurred in the previous decade ${ }^{19}$. Thus, the presupposition that this disease had already been notified is reasonable. At that time, the control program required the demonstration of infected snails to start a search for cases and any action to control transmission. 


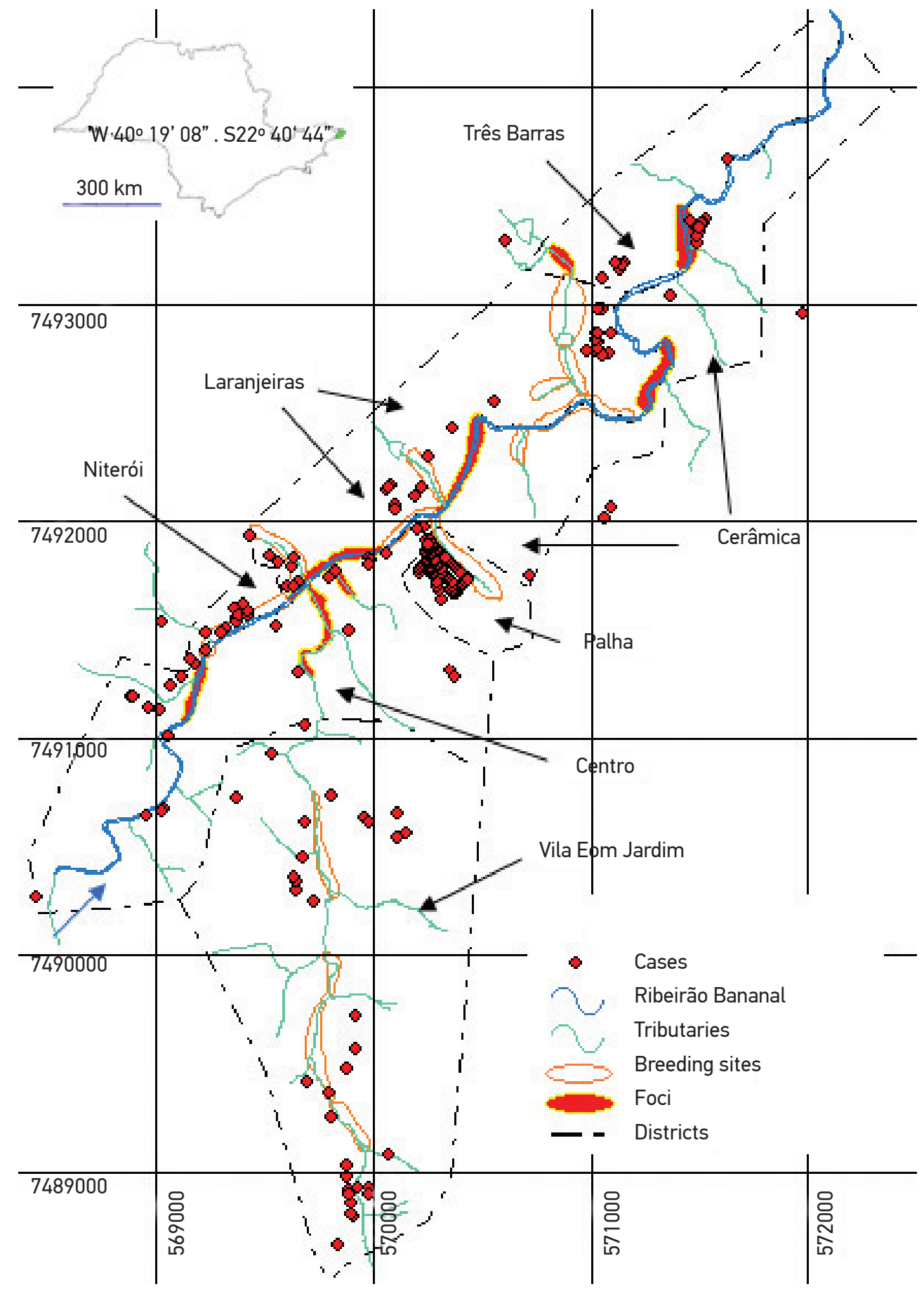

Figure 2. Delineation of outbreaks and distribution of schistosomiasis mansoni cases diagnosed in Bananal, São Paulo, Brazil (1994-2012). 


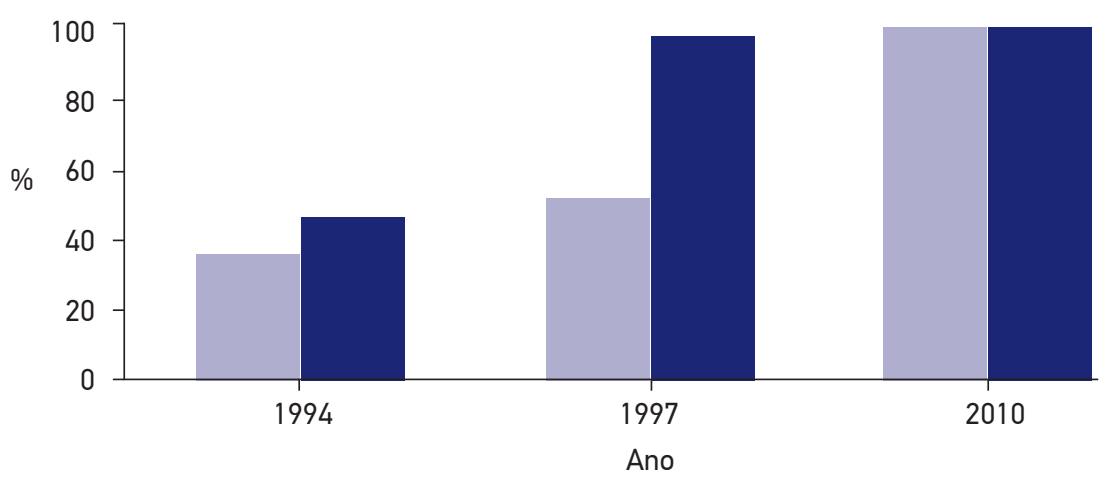

Collection and treatment of sewage $\quad$ Distribution of trested water

Figure 3. Evolution levels of care homes for the sewage network in Bananal, São Paulo, Brazil (SEADE ${ }^{12}$ ).

A recent study by Silva et al. ${ }^{20}$ showed that, currently, besides leisure, washing clothes, and kitchenware, and the removal of sand and stones from rivers or lakes for construction work, are examples of activities which involve contact with infected river water and infection with $S$. mansoni.

Taking into consideration the sanitary conditions now prevailing in Bananal as a result of parasite control plans, the continuity of the transmission of schistosomiasis is not to be expected. It is true that presumably some infected cases are remaining, or have been imported from other municipalities. Parasites may develop resistance to the drugs, and infected snails might unpredictably survive in previously cleaned water bodies. Such problems can constitute obstacles for the eradication of schistosomiasis in Bananal due to the discontinuity of the control program. As the prevalence of the infection decreases, new problems arise. Smaller egg production and irregularity of egg migration to the intestinal lumen, in addition, the development of immunity ${ }^{21,22}$ can make it difficult to identify positive cases. Thus, it may be necessary to examine more samples and greater masses of feces than in previous routine work.

In Bananal, from the year 2001 onwards, we started to examine two slides from each fecal sample, in addition to higher volumes of feces per slide, using, as routine techniques, microscopy of pressed fecal samples and serological examinations $s^{21,23}$. Such routine was responsible for the maintenance of the efficiency of the active surveillance of new cases during the interval from 2001 to 2003 . At the end of this interval, positive serological results led to examination of as much as 10 slides from one fecal sample to confirm a serological result. Thus, the calculated number of cases of schistosomiasis became more reliable. The records from 2003 correspond to the last notifications of cases pertaining to the municipality of Bananal, kept in the National System of Grievances and Notifications ("Sistema Nacional de Notificação de Agravos"). The municipality did not ratify the hypothesis of the finding of atypical worm eggs in tissue sections. 
The general consensus is that, given a set of circumstances comparable to those found in Bananal, asymptomatic cases are predominant ${ }^{1}$. However, before classifying a case as asymptomatic a close investigation is necessary. Otherwise, further investigation will be required to reveal important symptoms of the infection ${ }^{24}$. The clinical diagnosis should be the responsibility of adequately trained medical practitioners.

The planning for the eradication of schistosomiasis in Bananal involved a comprehensive action aimed at multiple aspects of the epidemiological problem under investigation. It is well known that the success of the eradication of this parasite depends on multiple factors, a variable amount of which are out of our control. From the year 2002 onwards, the routine search for snails infected with S. mansoni larvae failed to show any positive results. Before 2001, an inspection of maps had shown seeming random distribution of the sites where naturally infected snails had been discovered. Thus, an active search for such foci within selected perimeters was indicated, independently of prospects. Another important fact concerning mapping households was the observation that infected people were clustered in districts situated downstream with respect to the sites where cercaria-shedding snails had been identified. Thus, a passive spread of $S$. mansoni $i^{25}$ cercariae occurred from a distance of $1,200 \mathrm{~m}$ (at least) from the locality in which they were being shed. Another important observation was that a small number of carriers resident in an infected upstream district were enough to keep a focus in activity and create risks of infection among people resident in downstream districts, such as Palha and Cerâmica. It should be concluded that fixing the limits of a new focus of infected snails is not enough to define a region within which there is a risk of infection.

The use of the geographical information system - or geoprocessing — in planning the fight against and evaluation of the risks of the spread of schistosomiasis has also been the subject of studies in Brazil ${ }^{26-30}$. In general, the results of these studies bring together such diversified parameters such as the characteristics of the vegetation, temperature changes, availability of water collections, occurrence of species of intermediate hosts, as well as the distribution of cases and foci. This necessarily complicates the choice of priorities and planning activities designed to control and survey an epidemic.

Within the range of conditions observed in Bananal, peculiarities and the epidemiological reality arising from the urban ambience of the transmission of $S$. mansoni required the development of models of spatial analysis that aggregate conditions which transcend those usual in large-scale studies. The urban condition of schistosomiasis transmission in Bananal indicates the necessity of the adoption of different biological parameters, the quality of water supply, which can have an influence on the predictive value of the information collected.

Despite the colonization of water bodies in the municipality by B. tenagophila, the resumption of transmission of $S$. mansoni levels observed until the beginning of the century seem unlikely. The current situation indicates a trend for the elimination of the problem if the sanitary conditions are preserved. The surveillance aimed at the discovery and treatment of new cases should be preserved.

Finally, it is worth recording that the successful control of schistosomiasis transmission in Bananal highlights the need to develop flexible control programs or plans. A control of 
the evolution of work by means of a regular analysis of indicators and results is necessary. The use of different and complementary techniques on each epidemiological stage and the insertion of surveillance in routine health programs run by the municipality, such as Family Health Program, are absolutely essential.

\section{CONCLUSIONS}

The results show a real possibility of final disposal of the schistosomiasis transmission to the development of specific control plans that incorporate improvements in the sanitary conditions, despite the gradual loss of efficiency from the other prophylactic instruments in lower prevalences among others, as the possibility of the development of resistence to drugs available for treatment of cases.

It became evident that the need for attention to the existence of human infection by $S$. mansoni in people who came in contact with the freshwater environments, due to capacity of cercariae passive dispersion over long distances, include localities without the occurrence of snails (intermediate hosts of parasite), with a chance of increasing the incidence cases and developing of the disease.

\section{ACKNOWLEDGMENTS}

We thank Dr. Luis Filipe Mucci for processing spatial data and employees João Batista dos Santos and Ana Lúcia Guimarães Medeiros dos Santos, respectively, for their support in field and laboratory work.

\section{REFERENCES}

1. World Health Organization. The control of schistosomiasis. Geneva, 1985 (WHO - Tech Rep Series no. 728). p.99.

2. Katz N, Almeida K. Esquistossomose, xistosa, barriga d'água. Ci e Cult 2003; 55: 38-41.

3. Paraense WL. Distribuição dos caramujos no Brasil. An Acad mineira Med 1976; 14 (Suppl): 117-28.

4. Machado PA. Programa Especial de Controle da Esquistossomose. O modelo. In: Painel Programa Especial de Controle da Esquistossomose. Brasil, Ministério da Saúde. VI Conferência Nacional de Saúde, 1977. p. 1-9.

5. Katz N, Chaves A, Pellegrino J. Simple device for quantitative stool thick-smear technique in schistosomiasis mansoni. Rev Inst Med Trop S Paulo 1972; 14: 397-400.
6. Piza JT, Magalhães LA. Plano para o Combate à Esquistossomose Mansônica no Estado de São Paulo. São Paulo, Secretaria de Estado da Saúde, 1965 (Mimeo).

7. CACEsq. I Encontro Nacional sobre Esquistossomose. São Paulo, Secretaria de Estado da Saúde, Campanha de Combate à Esquistossomose, 1973. p.233.

8. Teles HMS. Distribuição geográfica das espécies dos caramujos transmissores de Schistosoma mansoni no Estado de São Paulo. Rev Soc Bras Med Trop 2005; 38: 426-32.

9. Piza JT. I. Expansão da esquistossomose no Estado de São Paulo. II. Medidas adotadas para o seu controle. Reunião Anual da Sociedade Brasileira para o Progresso

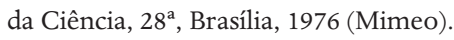


10. Teles HMS, Ciaravolo RMC, Lima VLC. Controle da esquistossomose mansônica no Estado de São Paulo. Bol Epidemiol Paul 2006; 3(Suppl 1): 19-26.

11. IBGE. Censo Demográfico 2010. Brasil, Ministério do Planejamento, Orçamento e Gestão, Instituto Brasileiro de Geografia e Estatística. Available from: www.ibge.gov.br (accessed 04/23/2012).

12. SEADE. Anuário Estatístico do Estado de São Paulo 2010. São Paulo, Secretaria de Planejamento e Desenvolvimento Regional, Fundação Sistema Estadual de Análise de Dados. Available from: www. seade.gov.br (accessed 04/21/2012).

13. Lutz A. O Schistosomum mansoni e a schistosomatose, segundo observações feitas no Brasil. Mem Inst Oswaldo Cruz 1919; 11: 121-55.

14. Hoffman WA, Pons JA, Janer JL. The sedimentationconcentration method in the schistosomiasis mansoni. Puerto Rico J Publ Health Trop Med 1934; 9: 283-91.

15. CVE. Vigilânca epidemiológica e controle da esquistossomose. São Paulo, Secretaria de Estado da Saúde, Centro de Vigilância Epidemiológica, 2006. p. 45 .

16. Coutinho JO. Índice de infestação natural dos planorbídeos pelas cercárias de Schistosoma mansoni, na cidade de Salvador - Bahia. An Fac Med Univ São Paulo 1950; 25: 23-53.

17. Teles HMS, Ferreira CS, Carvalho ME, Lima VR, Zacharias F. Schistosomiasis mansoni in Bananal (State of São Paulo, Brazil). II. Intermediate hosts. Mem Inst Oswaldo Cruz 2002; 97(Suppl I): 37-41.

18. Silva LJ. Sobre a antigüidade de alguns focos da esquistossomose no Estado de São Paulo. Rev brasil Malariol D Trop 1983; 35: 73-8.

19. Ramos AS, Piza JT, Camargo LSV. Observações sobre Australorbis tenagophilus, transmissor da esquistossomose mansônica. Arq Hig Saúde Públ 1961; 26: 121-4.

20. Silva RA, Carvalho ME, Zacharias F, Lima VR, Teles HMS. Schistosomiasis mansoni in Bananal (State of São Paulo, Brazil). IV. Study on the public awareness of its risks in the Palha District. Mem Inst Oswaldo Cruz 2002; 97(Suppl I): 15-8.

21. Teles HMS, Ferreira CS, Carvalho ME, Zacharias F, Magalhães LA. Eficiência do diagnóstico de Schistosoma mansoni em amostras de fezes prensadas. Rev Soc Bras Med Trop 2003; 36: 503-7.
22. Gryssels B. Uncertainties in the epidemiology and control of schistosomiasis. Am J Trop Med Hygiene 1996; 55: 103-8.

23. Zacharias F, Carvalho ME, Gargioni C, Teles HMS, Ferreira CS, Lima VR. Schistosomiasis mansoni in Bananal (State of São Paulo, Brazil). III. Seroepidemiological studies in the Palha District. Mem Inst Oswaldo Cruz 2002; 97(Suppl I): 19-22.

24. Espírito Santo MCC, Azeredo LM, Teles HMS, Gryschek RCB, Ferreira CS, Amato Neto V. Abdominal ultrasound in the evaluation of fibrosis and portal hypertension in an area of schistosomiasis low endemicity. Rev Inst Med trop S Paulo 2008; 50: 117-9.

25. Paraense WL, Santos JN. Um ano de observações sôbre a esquistossomose em planorbídeos da Lagoa Santa. Rev Brasil Malariol 1953; 5: 253-69.

26. Bavia ME, Hale LE, Malone JB, Braud DH, Shane SM. Geographic information systems and the environmental risk of schistosomiasis in Bahia, Brazil. Am J Trop Med Hyg 1999; 60: 566-72.

27. Bavia ME, Malone JB, Hale L, Dantas A, Marroni L, Reis R. Use of thermal and vegetation index data from earth observing satellites to evaluate the risk of schistosomiasis in Bahia, Brazil. Acta Trop 2001; 79: 77-85.

28. Barbosa CS, Araujo KC, Antunes L, Favre T, Pieri OS. Spatial distribution of schistosomiasis foci on Itamaracá Island, Pernambuco, Brazil. Mem Inst Oswaldo Cruz 2004; 99(Suppl I): 79-83.

29. Freitas CC, Guimarães RJPS, Dutra LV, Martins FT, Gouvêa EJC, Santos RAT, et al. Remote sensing and geographic information systems for the study of schistosomiasis in the State of Minas Gerais, Brazil. Available from: http://mtc-m12.sid.inpe.br/ col/sid.inpe.br/mtc-m12@80/2006/08.07.18.01/ doc/04_05A01.pdf (accessed 03/30/2009).

30. Guimarães RJPS, Freitas CC, Dutra LV, Moura ACM, Amaral RS, Drummond SC, et al. Analysis and estimative of schistosomiasis prevalence for the state of Minas Gerais, Brazil, using multiple regression with social and environmental spatial data. Mem Inst Oswaldo Cruz 2006; 101(Suppl I): 91-6.

Received on: 06/26/2013

Final version presented on: 12/04/2013

Accepted on: 12/05/2013 